P-ISSN 2580 - 7781

E-ISSN 2615 - 3238

\title{
UJI KOMPETENSI GUNA MENINGKATKAN PROFESIONALISME GURU SLTA DI DINAS PENDIDIKAN DAN KEBUDAYAAN KABUPATEN BUNGO
}

\author{
USE OF COMPETENCY TEST INCREASES PROFESSIONALISM OF \\ TEACHERS IN THE PRIVATE VOCATIONAL SCHOOL OF EDUCATION \\ AND CULTURE
}

\author{
Hamirul \\ STIA Setih Setio Muara Bungo \\ Email: hrul@ymail.com
}

\begin{abstract}
ABSTRAK
Artikel ini bertujuan untuk mengetahui bahwa Uji Kompetensi yang dilakukan oleh pemerintah dalam meningkatkan Profesionalisme guru dan apa saja yang menjadikan hambatan dan upaya apa saja yang dilakukan oleh dinas pendidikan dan kebudayaan kabupaten Bungo dalam rangka meningkatkan Profesionalisme Guru dan dengan menggunakan metode penelitian Deskriptif dan dengan pendekatan kualitatif dengan informan sebanyak 10 orang dan dihasilkan bahwa Kebijakan Pemerintah melalui Dinas Pendidikan dalam Pelaksanaan Uji Kompetensi guna meningkatkan Profesionalisme Guru SLTA mengacu kepada peraturan yang ada Surat Edaran Resmi Dirjen Nomor 2825/B/PR/2017 tertanggal 14 Agustus 2017 tentang Pelaksanaan UKG tahun 2017 telah dilakukan secara proporsional dan sesuai Surat Edaran Resmi Dirjen GTK yang dikemukakan di atas. Adapun hambatan yang dihadapi oleh Dinas Pendidikan Kabupaten Bungo dalam pelaksanaan uji kompetensi guna meningkatkan profesionalisme guru SLTA antara lain hambatan teknis tidak terkoneksi dengan jaringan internet karena pemadaman listrik, dan masih ada sebagian guru yang gagap teknologi (gaptek), serta tidak liniernya antara bidang mata pelajaran dengan soal UKG. Upaya yang dilakukan oleh Dinas Pendidikan Kabupaten Bungo dalam mengatasi hambatan yang dihadapi sehubungan dengan pelaksanaan uji kompetensi guna meningkatkan profesionalisme guru SLTA adalah berkoordinasi dengan pihak PLN mengenai hari dan jadwal pelaksanaan UKG serta menyiapkan mesin genset, bekerjasama dengan operator TUKG untuk memberikan pelatihan singkat dan memandu guru tersebut tentang tata cara mengoperasikan komputer dan internet pada aplikasi UKG, serta Mengikutsertakan guru pada Uji Kompetensi di Awal (UKA) yang dilakukan secara Online.
\end{abstract}

Kata Kunci: UKG, Profesionalisme, Guru, Dinas Pendidikan dan Kebudayaan, Bungo

\section{ABSTRACT}

This article aims to find out that the Competency Test conducted by the government in improving teacher professionalism and what are the obstacles and efforts made by the Bungo district education and culture service in order to improve Teacher Professionalism and by using descriptive research methods and with a qualitative approach with informants as many as 10 people and produced that the Government Policy through the Department of Education in the Implementation of Competency Tests to improve the Professionalism of Senior High School Teachers refers to the existing regulations Dirjen Official Circular No. 2825 / B / PR / 
P-ISSN $2580-7781$

E-ISSN 2615 - 3238

2017 dated August 14, 2017 concerning the Implementation of UKG in 2017 in terms of This is addressed to all Education Offices in the Province and Head of Education Offices in the District / City on Implementation (UKG) in 2017 which has been carried out proportionally and in accordance with the Official Circular of the Director General of GTK stated above. The obstacles faced by the Bungo District Education Office in the implementation of competency tests to improve the professionalism of high school teachers include technical barriers not connected to the internet due to power outages, and there are still some teachers who are technologically illiterate (gaptek), and are not linear between subject areas with UKG questions. Efforts made by the Bungo District Education Office in overcoming obstacles encountered in connection with the implementation of competency tests to improve the professionalism of high school teachers are coordinating with the National Electricity Company regarding the day and schedule for UKG implementation and preparing generator sets, in collaboration with TUKG operators to provide short training and guide teachers is about the procedures for operating computers and the internet in the UKG application, and Engaging teachers in the Competency Test in the Beginning (UKA) conducted online.

Keywords: UKG, Professionalism, Teachers, Education and Culture Office, Bungo

\section{PENDAHULUAN}

Pendidikan nasional mempunyai tujuan untuk mencerdaskan kehidupan bangsa dan mengembangkan manusia seutuhnya, maka sangat dibutuhkan peran serta pendidik yang profesional. Hal ini tertuang dalam Undang-undang Republik Indonesia Nomor 20 Tahun 2003 tentang Sistem Pendidikan Nasional, dimana guru sebagai pendidik yang profesional. Undang-Undang Nomor 14 Tahun 2005 tentang Guru dan Dosen mengamanatkan bahwa guru adalah pendidik profesional dengan tugas utama mendidik, mengajar, membimbing, mengarahkan, melatih, menilai, dan mengevaluasi peserta didik pada pendidikan anak usia dini jalur pendidikan formal, pendidikan dasar, dan pendidikan menengah.

Guru harus memiliki kualifikasi akademik minimum sarjana (S-1) dan setaranya menguasai kompetensi (pedagogik, profesional, sosial dan kepribadian), dan memiliki sertifikat untuk mendidik, serta sehat jasmani dan rohani, memahami dan memiliki kemampuan untuk mewujudkan tujuan pendidikan nasional. Guru yang profesional harus mempuyai keinginan untuk selalu berkembang sesuai dengan tuntutan zaman, serta melengkapi diri dengan ilmu pengetahuan dan teknologi, serta dapat memenuhi kebutuhan masyarakat. 
P-ISSN 2580 - 7781

E-ISSN 2615 - 3238

Undang-Undang Nomor 14 Tahun 2005 tentang Guru dan Dosen memberikan definisi professional yang dimaksud adalah pekerjaan atau kegiatan yang dilakukan oleh seseorang untuk memenuhi kehidupan dengan memanfaatkan keahlian, kemahiran, serta kecakapan yang sesuai kompetensi yang harus dimiliki oleh seorang yakni kompetensi Pedagogik, Kompetensi Sosial, Kompetensi Kepribadian, Kompetensi Profesional dan Sebagai tenaga profesional, guru harus mengembangkan dirinya secara kontinyu serta meningkatkan kualitas pengetahuan sesuai dengan tuntutan zaman.

Kompetensi (competence) mempunyai pengertian cakap atau memiliki kemampuan. W. Robert Houston dalam Roestiyah mengartikan bahwa suatu tugas yang memadai, serta memiliki pengetahuan, keterampilan dan kemampuan yang sesuai dengan jabatan yang disandangnya. Defenisi ini memahami, dalam diri manusia ada suatu potensi tertentu yang dikembangkan dan dapat dijadikan sebagai motivator, yakni kekuatan dari dalam diri individu tersebut. Pengertian di atas lebih difokuskan pada tugas guru dalam mendidik.

Nana Sudjana memberikan pengertian bahwa kompetensi sebagai suatu kemampuan yang harus dimiliki untuk menjalankan profesi yang dijalaninya. Sardiman mengartikan kompetensi adalah kemampuan yang harus dimiliki seseorang sesuai dengan keahliannya. Kedua pengertian tersebut diatas bahwa kompetensi adalah keahlian guru dalam mengembangkan empat kompetensi yang dimilikinya.

Dalam Undang-undang No. 14 Tahun 2005 tentang Guru dan Dosen pasal 1 ayat 10 memberikan pengertian bahwa kompetensi adalah seperangkat pengetahuan serta keterampilan, dan perilaku yang harus dimiliki, dihayati, dan dikuasai oleh guru atau dosen dalam melaksanakan tugas keprofesionalan".

Para ahli pendidikan menyatakan bahwa kompetensi beraneka ragam. Keragaman komponen tersebut diantaranya disebabkan pada sudut pandang, wawasan, dan konteks waktu. Cooper dalam Nana Sudjana memberikan penjelasan bahwa, komponen kompetensi diklasifikasikan menjadi beberapa kategori, yaitu : 
P-ISSN 2580 - 7781

E-ISSN 2615 - 3238

1. Mengetahui pengetahuan tentang belajar dan tingkah laku manusia.

2. Mempunyai pengetahuan dan menguasai bidang studi yang diampunya.

3. Mempunyai sikap yang tepat tentang dirinya.

4. Mempunyai keterampilan tentang tehnik mengajar.

Identik dengan Cooper, Glasser menjelaskan bahwa ada empat (4) hal dasar yang harus dikuasai guru, yaitu :

1. Menguasai bahan pelajaran.

2. Kemampuan mendiagnosa tingkah laku siswa.

3. Kemampuan melaksanakan proses pengajaran.

4. Kemampuan mengukur hasil belajar siswa.

Lebih lanjut menurut Roestiyah, kompetensi ataupun kemampuan dasar yang harus dimiliki seorang guru sebagaimana yang dilakukan pada Proyek Pembinaan Pendidikan Guru (P3G), paling tidak meliputi 10 komponen pokok, yaitu :

1. Menguasai bahan, meliputi bahan bidang studi dan kurikulum sekolah, aplikasi bidang studi, menguasai bahan dan metodologinya serta menguasai bahan untuk bidang studi yang terspesialisasi.

2. Mengelola program belajar dan mengajar, diantaranya perumusan tujuan instruksional, menggunakan metode mengajar, memilih dan menyusun prosedur pengajaran yang tepat, melaksanakan program belajar mengajar, mengenal potensi anak, perencanaan dan pelaksanaan remedial.

3. Mengatur kelas serta mengelola, meliputi pengaturan tata ruang kelas untuk pengajaran dan menciptakan iklim belajar yang serasi.

4. Menggunakan media/sumber, meliputi kemampuan mengenal, memilih dan melaksanakannya dalam proses belajar mengajar, membuatnya, pengelolaan dan menggunakan laboratorium dalam proses belajar mengajar, dan penggunaan perpustakaan sebagai sumber belajar.

5. Menguasai landasan-landasan kependidikan, seperti psikologi pendidikan, psikologi perkembangan anak dan lainnya. 
P-ISSN 2580 - 7781

E-ISSN 2615 - 3238

6. Mengelola interaksi belajar dan mengajar.

7. Menilai prestasi siswa untuk penilaian hasil pembelajaran.

8. Pelaksanaan bimbingan dan penyuluhan.

9. Penyelenggaraan administrasi sekolah.

10. Penggunaan hasil-hasil penelitian kependidikan.

(Sanaky, 2005) Menyatakan, "Profesionalisme guru seharusnya mempunyai keterkaitan dalam hal membangun konstruksi belajar melalui penguasaan kompetensi-kompetensi yang secara nyata dalam menjalankan dan menyelesaikan tugas-tugas dan pekerjaannya sebagai guru. Berbicara tentang profesionalisme guru sangat komprehensif. Profesi guru harus dari kemampuan menguasai kurikulum, materi pembelajaran, teknik dan metode pembelajaran, kemampuan mengelola kelas, komit pada tugas, dapat menjaga kode etik profesi, disekolah ia harus menjadi manusia model yang akan ditiru siswanya, dimasyarakat menjadi tauladan. Profesionalisme guru dijabarkan melalui penguasaan kompetensi-kompetensi yang secara nyata sangat diperlukan dalam hal menyelesaikan pekerjaannya sebagai guru. Kompetensi-kompetensi penting jabatan guru tersebut adalah kompetensi bidang substansi atau bidang studi, kompetensi bidang pembelaran dan kompetensi bidang pendidikan nilai dan bimbingan serta kompetensi bidang hubungan dan pelayanan/ pengabdian masyarakat. Pengembangan Profesionalisme guru meliputi peningkatan kompetensi, peningkatan kinerja (Performance) dan kesejateraannya”.

(Nurhayati, 2006) dari hasil penelitiannya ada beberapa hal yang mempengaruhi Profesionalisme adalah: Tingkat kesejateraan guru ( gaji guru), kualifikasi atau tingkat pendidikan guru, masa kerja, pengalaman kerja dan latihan yang, penguasaan kompetensi sosial, Pedagogik, pribadi dan professional, kepemimpinan kepala sekolah yang demokratis, iklim kerja di sekolah kondusif, dukungan positif dari anggota keluarga guru dirumah terhadap aktivitas mengajar disekolah, dukungan moral dari dewan sekolah, peserta didik, komite sekolah dan masyarakat terhadap pengabdian guru dalam mengajar disekolah, dukungan biaya 
pendidikan yang memadai dari orang tua peserta didik, masyarakat, dan pemerintah, dukungan infra struktur dan fasilitas pendidikan dan orang tua peserta didik, masyarakat dan pemerintah dan dukungan berbagaisumberdaya pendidikan lainnya dari para stakeholders pendidikan di sekolah.

Di Kabupaten Bungo, UKG diikuti oleh semua guru dalam jabatan baik guru PNS maupun bukan PNS. Namun berdasarkan hasil pengamatan awal yang peneliti lakukan dapat diketahui bahwa terdapat beberapa permasalahan dalam pelaksanaan UKG tersebut. Permasalahan yang terjadi adalah guru yang memperoleh soal UKG tidak sesuai dengan kompetensi keahlian atau sertifikasi guru yang bersangkutan dan kepala sekolah dikategorikan sebagai guru kelas, bukan guru mata pelajaran. Ketidaksinkronan itu dengan uji kompetensi yang diujikan tentu tidak akan memberikan informasi tentang gambaran kompetensi guru, khususnya kompetensi guru secara keseluruhan dan dengan adanya UKG dapat meningkatkan kompetensi guru itu secara keseluruhan terutama di kabupaten Bungo.

Berdasarkan beberapa permasalahan di atas, maka rumusan masalah dalam penelitian ini adalah Bagaimana pelaksanaan uji kompetensi guru dalam rangka meningkatkan profesionalisme guru SLTA di Kabupaten Bungo ?

\section{METODOLOGI PENELITIAN}

Penelitian ini menggunakan analisis deskriptif dengan metode kualitatif dengan informan sebanyak 10 orang yang terdiri dari pegawai dan staff Dinas Pendidikan dan Kebudayaan Kabupaten Bungo dengan menggunakan analisis deskriptif serta trianggulasi.

\section{PEMBAHASAN}

Permasalahan guru selalu mendapat perhatian, baik oleh pemerintah maupun oleh masyarakat pada umumnya dan oleh ahli pendidikan khususnya. Pemerintah memandang guru merupakan hal yang sangat penting artinya dalam kerangka 
pembinaan dan pengembangan bangsa. Guru mengemban tugas-tugas sosial kultural yang berfungsi mempersiapkan generasi muda sesuai dengan cita-cita bangsa. Mutu guru turut menentukan mutu pendidikan. Sedangkan mutu pendidikan akan menentukan mutu generasi muda sebagai calon warga negara dan warga masyarakat. oleh karena itu dalam rangka mencapai tujuan pendidikan diperlukan peran serta guru yang profesional.

Hal ini sejalan dengan Undang-undang Republik Indonesia Nomor 20 Tahun 2003 tentang Sistem Pendidikan Nasional, bahwa jabatan guru sebagai pendidik merupakan jabatan profesional. Untuk itu, profesionalisme guru dituntut terus berkembang sesuai dengan perkembangan zaman, perkembangan ilmu pengetahuan dan teknologi, serta kebutuhan masyarakat.

Berdasarkan hasil penelitian, bahwa di Kabupaten Bungo kebijakan pemerintah melalui Dinas Pendidikan dalam pelaksanaan uji kompetensi guna meningkatkan profesionalisme guru SLTA mengacu kepada Surat Edaran Resmi Dirjen Nomor 2825/B/PR/2017 tertanggal 14 Agustus 2017 tentang Pelaksanaan UKG tahun 2015 yang ditujukan kepada seluruh kepala Dinas Pendidikan Provinsi dan Kepala Dinas Pendidikan Kabupaten/Kota tentang Pelaksanaan Uji Kompetensi Guru (UKG) tahun 2017.

Di dukung oleh hasil wawancara dengan Sekretaris Dinas Pendidikan Kabupaten Bungo,

“...bahwa di dalam surat edaran tersebut disampaikan bahwa dalam rangka pemetaan kompetensi pedagogik dan profesional guru sesuai bidang atau mata pelajaran yang diampu, maka Direktorat Jenderal Guru dan Tenaga Kependidikan Kementerian Pendidikan dan kebudayaan akan melaksanakan Uji Kompetensi Guru (UKG) pada tahun anggaran 2017 terhadap 3.015.315 orang guru di seluruh Indonesia pada pertengahan bulan November 2017 secara online bagi sekolah kabupaten/kota yang sudah siap dan secara offline bagi 
E-ISSN 2615 - 3238

kabupaten/kota yang belum siap ${ }^{1}$. Ditambahkan oleh beliau bahwa siap di sini maksudnya pelaksanaan UKG sudah difasilitasi dengan sarana dan prasarana teknologi komputer dan jaringan internet yang mudah di akses oleh peserta UKG. Sedangkan untuk kabupaten/kota yang belum siap maksudnya masih dihadapkan oleh keterbatasan sarana dan prasarana pendukung pelaksanaan UKG, seperti komputer dan jaringan internet".

Pendapat senada juga disampaikan oleh Bapak Indrayani, “...bahwa Dinas Pendidikan hanya memfasilitasi pelaksanaan UKG. Sedangkan kebijakannya mengacu kepada Surat Edaran Resmi Dirjen GTK Nomor 2825/B/PR/2015 tertanggal 14 Agustus 2015 tentang Pelaksanaan UKG tahun 2015. UKG ini adalah program nasional Kemendikbud".

Diuraikan pula dalam surat edaran tersebut bahwasanya UKG online maupun offline yang telah dilaksanakan pada tahun 2017 bagi guru dan kepala sekolah memiliki nilai rata-rata sebesar 4,7. Sehingga dalam rangka memenuhi target Rencana Pembangunan Jangka Menengah Nasional (RPJMN) Kementerian Pendidikan dan Kebudayaan yaitu yaitu rata-rata kompetensi guru tahun 2019 yang akan datang mencapaia angka 8.00 (delapan).

Maka Dirjen GTK menyampaikan permohonan kepada Kepala Dinas Pendidikan Provinsi dan Kepala Dinas Pendidikan Kabupaten/Kota untuk memotivasi para guru dan kepala sekolah untuk meningkatkan profesinya. Selanjutnya untuk keterlaksanaan UKG 2017 Dirjen GTK menginstruksikan agar Dinas Pendidikan Provinsi dan Kepala Dinas Pendidikan Kabupaten/Kota mengadakan sosialisasi pelaksanaan UKG serta menyiapkan infrastruktur tempat pelaksanaan UKG serta mempersiapkan pelaksanaan UKG secara nasional yang dikoordinir oleh Dirjen GTK.

Terkait dengan masalah sosialisasi pelaksanaan UKG, menurut hasil wawancara dengan Kasubbag Program Dinas Pendidikan Kabupaten Bungo, diikuti 


\section{P-ISSN 2580 - 7781}

E-ISSN 2615 - 3238

oleh Kepala TK/ SD/ SMP/ SMA/ SMK Negeri dan Swasta sekabupaten Bungo. Pelaksanaan UKG melibatkan berbagai instansi antara lain BPSDMPK-PMP, LPMP, dan Dinas Pendidikan Kabupaten/Kota. Agar seluruh instansi yang terlibat dalam pelaksanaan UKG memiliki pemahaman yang sama tentang mekanisme pelaksanaan, maka perlu informasi yang lengkap tentang mekanisme pelaksanaan UKG Tahun 2017 baik disisi tujuan dan manajemen berbasis NUPTK yang terintegrasi dengan data Dapodik. Selain itu materi sosialisasi juga membahas tentang kemungkinan kendala teknis yang dihadapi pada saat pelaksanaan dan bagaimana cara mengatasinya.

Selain itu ditegaskan oleh Indrayani,

“....bahwa tujuan UKG untuk pemetaan kompetensi guru (kompetensi pedagogik dan profesional), melaksanakan program pembinaan dan pengembangan profesi guru dalam bentuk kegiatan pengembangan keprofesian berkelanjutan (pelatihan) serta sebagai alat kontrol pelaksanaan penilaian kinerja guru (PKG). UKG tahun 2017 tidak jauh berbeda dari tahun sebelumnya, salah satunya dari standar nilai kelulusan sebesar 5,5 sebagaimana yang telah ditetapkan oleh pemerintah pusat. Apabila guru atau peserta UKG tidak memenuhi nilai dengan kata lain tidak lulus guru bersangkutan akan dikelompokkan dan akan mengikuti pembinaan guna untuk meningkatkan kemampuannya sebagai seorang pendidik sehingga mereka mampu di ujian berikutnya".

Sementara itu berdasarkan hasil wawancara dengan Mukhlis menyatakan, “ dalam pelaksanaan UKG 2017, tugas Dinas Pendidikan Kabupaten Bungo adalah sebagai berikut :

1. Membentuk kepanitiaan UKG.

2. Menetapkan lokasi pelaksanaan UKG.

3. Menginformasikan maksud dan tujuan UKG.

4. Penempatan peserta ke TUK.

5. Pembekalan penggunaan aplikasi UKG ke admin.

6. Mencetak dan mendistribusikan Kartu Peserta UKG.

7. Menginformasikan jadwal pelaksanaan UKG”. 
P-ISSN 2580 - 7781

E-ISSN 2615 - 3238

Adapun kriteria guru yang menjadi peserta UKG pada tanggal $9-27$ November tahun 2017 adalah sebagai berikut :

1. Semua guru baik yang sudah memiliki sertifikat pendidik maupun yang belum memiliki sertifikat pendidik.

2. Guru PNS dan bukan PNS yang terdaftar di dalam Data Pokok Pendidikan (Dapodik).

3. Memiliki NUPTK atau Peg. Id.

4. Masih aktif mengajar mata pelajaran sesuai dengan kualifikasi akademik dan/atau sesuai dengan bidang studi sertifikasi.

Sedangkan kriteria tempat uji kompetensi sebagaimana yang disyaratkan oleh

Surat Edaran Resmi Dirjen Nomor 2825/B/PR/2017 tertanggal 14 Agustus 2017 tentang Pelaksanaan UKG tahun 2017, adalah sebagai berikut :

1. Tempat Uji Kompetensi (TUK) adalah ruang laboratorium komputer yang dilengkapi dengan sarana yang lengkap untuk Uji Kompetensi Guru (Ruang laboratorium komputer pada unit kerja PPPPTK/LPPKS/LPPPTK-KPTK/LPMP, sekolah, atau organisasi profesi). Memiliki komputer minimal 20 unit PC dan 1 server, yang terkoneksi dalam jaringan LAN serta memiliki sumber daya manusia (admin/teknisi) yang memahami Local Area Network (LAN) dan terbiasa bekerja dengan jaringan internet.

2. TUK ditetapkan dinas pendidikan kabupaten/kota sesuai dengan persyaratan dan telah diverifikasi oleh LPMP.

3. Penentuan lokasi TUK disamping mempertimbangkan sarana juga letak geografis yang mudah dijangkau guru.

Untuk Kabupaten Bungo sendiri tempat pelaksanaan UKG secara online ditetapkan di empat (4) lokasi di wilayah Kabupaten Bungo. Ditetapkannya keempat tempat tersebut sebagai tempat pelaksanaan UKG karena keempat tempat tersebut terjangkau jaringan internet dan memiliki laboratorium komputer yang terkoneksi dalam jaringan LAN (Local Area Network). 
P-ISSN $2580-7781$

E-ISSN 2615 - 3238

Adapun lokasi tempat pelaksanaan UKG tersebut dapat di lihat pada tabel berikut ini :

Tabel 1

Tempat Pelaksanaan UKG di Kabupaten Bungo

\begin{tabular}{|c|l|l|}
\hline No & \multicolumn{1}{|c|}{ Tempat } & \multicolumn{1}{|c|}{ Keterangan } \\
\hline 1 & SMK Negeri 1 Muara Bungo & Komplek SKB Sei. Binjai \\
\hline 2 & SMK Negeri 3 Muara Bungo & Jl. Duren Kel. Bungo Dani \\
\hline 3 & SMK Setih Setio 2 Muara Bungo & Jl. Setih Setio No. 4 Kel. Pasir Putih \\
\hline 4 & SMP Xaverius Muara Bungo & Jl. Raden Mattaher Kel. Pasir Putih \\
\hline
\end{tabular}

Sumber : Dinas Pendidikan Kabupaten Bungo, 2017.

Adapun tata tertib ataupun tata cara mengikuti Uji Kompetensi Guru (UKG) secara online, sebagai berikut :

1. Setelah registrasi, peserta memasuki ruangan minimal 30 menit sebelum jadwal ujian dengan menunjukkan Kartu Peserta UKG online dan identitas lainnya.

2. Peserta mengisi daftar hadir dan mendengarkan pengarahan dari tim teknis.

3. Login pada sistem ujian online sesuai dengan nomor peserta UKG dan NUPTK.

4. Latihan menggunakan sistem ujian online selama 15 menit menggunakan soal ujicoba atau soal latihan.

5. Mengikuti ujian yang sesungguhnya dengan mengakses soal UKG yang disediakan.

6. Waktu ujian akan tampil di layar komputer dan mulai menghitung mundur saat soal ujian mulai diakses.

7. Menjawab soal ujian dengan cara memilih jawaban yang dianggap benar dengan menggunakan mouse atau menekan keyboard (huruf A, B, C atau D).

8. Jika terjadi salah pilih jawaban, peserta dapat memperbaiki jawaban dengan cara yang sama pada butir 7 di atas. Peserta dapat mengganti jawaban beberapa kali tanpa mengurangi nilai.

9. Soal akan tampil di layar komputer satu per satu.

10. Aplikasi UKG online akan berhenti secara otomatis pada saat waktu ujian berakhir. 
P-ISSN 2580 - 7781

E-ISSN 2615 - 3238

11. Peserta yang telah menyelesaikan ujian meninggalkan ruangan.

Berdasarkan uraian wawancara tersebut di atas dapat peneliti simpulkan bahwa kebijakan pemerintah melalui Dinas Pendidikan dalam pelaksanaan UKG guna meningkatkan profesionalisme Guru SLTA di Kabupaten Bungo mengacu kepada Surat Edaran Resmi Dirjen Nomor 2825/B/PR/2017 tertanggal 14 Agustus 2017 tentang Pelaksanaan UKG tahun 2017.

Uji Kompetensi Guru (UKG) telah terlaksana dan diikuti oleh semua guru, baik yang telah bersertifikat pendidik maupun yang belum memiliki sertifikat pendidik. Namun demikian pelaksanaan UKG tersebut masih mengalami beberapa hambatan. Adapun hambatan yang dihadapi oleh Dinas Pendidikan Kabupaten Bungo dalam pelaksanaan uji kompetensi guna meningkatkan profesionalisme guru SLTA, antara lain :

\section{Tidak terkoneksi dengan jaringan internet karena pemadaman listrik}

Kendala teknis tidak terkoneksi dengan jaringan internet disebabkan oleh 2 hal, yang pertama terjadinya pemadaman listrik, yang kedua muncul pesan "tidak terkoneksi dengan server" pada saat peserta melakukan login. Cara mengatasi kendala ini juga berbeda. Jika pemadaman yang terjadi pada saat para guru sedang mengikuti pelaksanaan uji kompetensi, akibatnya komputer mengalami kegagalan koneksi dengan server yang secara otomatis menghambat para guru dalam mengikuti uji kompetensi tersebut. Maka mengatasinya adalah dengan menghidupkan kembali listrik. Tetapi jika yang terjadi adalah masalah yang kedua, maka untuk mengatasinya diperlukan operator UKG. Meskipun telah dijelaskan oleh Kasi Pengelolaan Sistem Informasi bahwa jika tiba-tiba ada gangguan listrik padam, jawaban tidak akan hilang, karena komputer telah di program secara otomatis untuk menyimpan data atau jawaban yang telah di isi oleh para guru. ${ }^{2}$ Namun dari segi waktu tentu merugikan para guru. Waktu pelaksanaan ujian juga telah diatur oleh sistem. Salah satunya menurut pernyataan yang disampaikan oleh Ibu Desfi Hariani, S.Pd Guru Bahasa 
P-ISSN 2580 - 7781

E-ISSN 2615 - 3238

Indonesia Peserta UKG dari SMA Negeri I Tanah Tumbuh, bahwa sesuai dengan tata tertib pelaksanaan UKG waktu ujian akan tampil di layar komputer dan mulai menghitung mundur saat soal ujian mulai diakses dan kemudian aplikasi UKG online akan berhenti secara otomatis pada saat waktu ujian berakhir ${ }^{3}$. Pendapat senada juga disampaikan oleh Ibu Melsis Trijuniati Guru Sejarah Peserta UKG dari SMA Negeri I Tanah Tumbuh, bahwa pada saat hari pelaksanaan UKG, terjadi kegagalan terkoneksi dengan server akibat mati lampu. Meski waktu itu bisa segera diatasi tetapi tepat menimbulkan perasaan khawatir yang menyebabkan konsentrasi menurun. Semestinya segala sesuatunya telah dipersiapkan guna menghindari hal-hal yang tidak diinginkan ${ }^{4}$.

2. Masih ada sebagian guru yang gagap teknologi (gaptek)

Berdasarkan hasil wawancara dengan Ibu Samsidar, Guru Ekonomi Peserta UKG dari SMA Negeri I Tanah Tumbuh, bahwa banyak para guru mengeluh karena tidak semua cakap dalam menggunakan teknologi internet. Apalagi waktu pengerjaan soal juga telah diprogram dalam aplikasi UKG, sehingga pelaksanaan UKG ini dianggap terlalu tergesa-gesa.

3. Tidak liniernya antara bidang mata pelajaran dengan soal UKG

Materi UKG yang diikuti oleh guru bersertifikasi pendidik berbeda dengan guru yang belum bersertifikasi pendidik. Mata uji untuk guru bersertifikasi pendidik sama dengan bidang studi sertifikasi dan dinyatakan valid oleh BPSDMPK-PMP. Sedangkan untuk guru yang belum bersertifikasi pendidik, mata uji harus sesuai dengan S1/D-4 yang dimiliki. Bagi guru yang belum memiliki kualifikasi akademik S1/D-4 sesuai mata pelajaran yang sedang di ampu.

Menurut hasil wawancara dengan Kabid Data dan Informasi Pendidikan, masalah soal yang tidak valid dan tidak reliabel tidak hanya terjadi di Kabupaten Bungo, tetapi juga terjadi di Padang, Bukit Tinggi, dan Medan. Masalah ini meliputi 
soal atau jawaban yang tidak keluar sehingga membuat peserta menebak apa yang akan dijawabnya. Masalah lainnya adalah salah bidang studi, semisal guru SMK dengan jurusan tertentu diberi soal Bahasa Jepang ${ }^{5}$.

Hal ini dibenarkan oleh Kepala Dinas Pendidikan Kabupaten Bungo, beliau menghimbau agar para guru yang sudah bersertifikasi agar tidak takut mengikuti ujian kompetensi ini. Mereka harusnya siap meningkatkan kompetensinya sebagai seorang guru. Kalau punya kompetensi, kenapa harus takut ${ }^{6}$. Lagi pula soal yang keluar dalam UKG tergolong soal dengan tingkat kesulitan sedang. Menurutnya, UKG baik untuk guru karena guru dapat mengukur kemampuan dirinya melalui UKG.

Sebagai tenaga profesional, guru dituntut untuk selalu mengembangkan diri sejalan dengan kemajuan ilmu pengetahuan, teknologi, dan seni. Untuk itu dalam rangka mengatasi hambatan dalam pelaksanaan UKG, Dinas Pendidikan Kabupaten Bungo telah melakukan berbagai upaya guna meningkatkan profesionalisme guru SLTA. Berdasarkan hasil wawancara dengan Kasi Pengelolaan Sistem Informasi, ada beberapa upaya yang telah dilakukan antara lain :

1. Berkoordinasi dengan pihak PLN mengenai hari dan jadwal pelaksanaan UKG serta menyiapkan mesin genset.

Terjadinya pemadaman listrik di beberapa wilayah di Kabupaten Bungo bukanlah merupakan hal yang luar biasa. Namun keadaan ini menjadi luar biasa ketika pemadaman terjadi pada saat para guru sedang mengikuti pelaksanaan uji kompetensi, akibatnya komputer mengalami kegagalan koneksi dengan server yang secara otomatis menghambat para guru dalam mengikuti uji kompetensi tersebut.

Untuk mengatasi masalah tersebut, maka Dinas Pendidikan kabupaten Bungo telah berkoordinasi dengan pihak PLN mengenai pelaksanaan UKG yang dilakukan di beberapa tempat. Selain itu menurut penjelasan Bapak Indrayani, bahwa Dinas 
P-ISSN 2580 - 7781

E-ISSN 2615 - 3238

Pendidikan juga telah menyiapkan mesin genset di tempat pelaksanaan UKG sebagai alternatif jika pihak PLN tidak dapat menghidupkan listrik dengan segera.

2. Bekerjasama dengan operator TUKG untuk memberikan pelatihan singkat dan memandu guru tersebut tentang tata cara mengoperasikan komputer dan internet pada aplikasi UKG.

Tujuannya agar dapat mengatasi permasalahan yang timbul pada saat pelaksanaan UKG. Dengan adanya operator TUKG ini diharapkan pada pelaksanaan UKG segala permasalahan terkait dengan program komputer, tidak terkoneksi, soal yang tidak bisa dibuka, bisa di atasi sesegera mungkin.

Menurut wawancara dengan Bapak Mukhlis pada saat pelaksanaan UKG untuk mengatasi ketidakmampuan guru dalam mengoperasikan komputer dan internet, maka sebelum pelaksanaan UKG dimulai, terlebih dahulu diadakan pelatihan singkat tentang tata cara UKG, dan pada saat ujian mulai dilaksanakan operator UKG memandu para peserta UKG dalam mengoperasikan komputer dan internet.

Selain itu cara menjawab soal dalam pelaksanaan UKG memang disiapkan dalam dua cara, yaitu menggunakan mouse atau menggunakan keyboard. Bagi guru yang tidak terbiasa menggunakan mouse, dapat meminta bimbingan petugas di TUKG untuk menggunakan keyboard. Keyboard komputer di TUKG juga telah disiapkan hanya ada beberapa tombol yang bisa digunakan dalam aplikasi UKG.

3. Mengikutsertakan guru pada Uji Kompetensi Awal (UKA) secara Online.

Salah satu layanan bagi Guru untuk mempersiapkan diri adalah situs Uji Kompetensi Awal (UKA) online yang memberikan kesempatan besar bagi para guru untuk berlatih bagaimana mengerjakan soal yang polanya tidak berbeda jauh dengan Uji Kompetensi Guru Online.

Berdasarkan hasil wawancara dengan Kepala Dinas Pendidikan Kabupaten Bungo, bahwa Uji Kompetensi Awal (UKA) merupakan salah satu tahap yang harus diikuti oleh calon peserta. UKA mengukur kompetensi dasar tentang bidang studi yang sesuai dengan bidang studi sertifikasi (bagi guru yang sudah bersertifikat 
P-ISSN 2580 - 7781

E-ISSN 2615 - 3238

pendidik) dan sesuai dengan kualifikasi akademik guru (bagi guru yang belum bersertifikat pendidik) ${ }^{7}$.

Kompetensi pedagogik yang diujikan adalah integrasi konsep pedagogik ke dalam proses pembelajaran bidang studi tersebut dalam kelas. Instrumen tes untuk guru bidang studi pada jenjang SMP, SMA dan SMK tidak dibedakan karena secara akademik guru wajib menguasai kompetensi dasar lulusan sarjana (S-1) sesuai bidang studi yang ditempuhnya. Pengembangan instrumen UKA terdiri atas kisi-kisi dan butir soal. Soal UKA dikembangkan oleh Tim Ahli dengan bentuk soal obyektif tes jenis pilihan ganda dengan 4 opsi pilihan jawaban. Komposisi instrumen tes adalah $30 \%$ kompetensi pedagogik dan 70\% kompetensi profesional dengan waktu pengerjaan soal ujian adalah 120 menit dan jumlah soal maksimal 100 butir soal. Upaya ini diharapkan dapat mengatasi permasalahan ketidaklinieran antara bidang mata pelajaran dengan soal UKG.

\section{KESIMPULAN}

Dari beberapa poin pembahasan di atas, maka peneliti dapat memberikan kesimpulan sebagai berikut:

1. Kebijakan Pemerintah melalui Dinas Pendidikan dalam Pelaksanaan Uji Kompetensi guna meningkatkan Profesionalisme Guru SLTA mengacu kepada Surat Edaran Resmi Dirjen Nomor 2825/B/PR/2017 tertanggal 14 Agustus 2017 tentang Pelaksanaan UKG tahun 2017 yang ditujukan kepada seluruh kepala Dinas Pendidikan Provinsi dan Kepala Dinas Pendidikan Kabupaten/Kota tentang Pelaksanaan Uji Kompetensi Guru (UKG) tahun 2017 telah dilakukan secara proporsional dan sesuai Surat Edaran Resmi Dirjen GTK yang dikemukakan di atas.

2. Adapun hambatan yang dihadapi oleh Dinas Pendidikan Kabupaten Bungo dalam pelaksanaan uji kompetensi guna meningkatkan profesionalisme guru SLTA 
antara lain hambatan teknis tidak terkoneksi dengan jaringan internet karena pemadaman listrik, dan masih ada sebagian guru yang gagap teknologi (gaptek), serta tidak liniernya antara bidang mata pelajaran dengan soal UKG.

3. Upaya yang dilakukan oleh Dinas Pendidikan Kabupaten Bungo dalam mengatasi hambatan yang dihadapi sehubungan dengan pelaksanaan uji kompetensi guna meningkatkan profesionalisme guru SLTA adalah berkoordinasi dengan pihak PLN mengenai hari dan jadwal pelaksanaan UKG serta menyiapkan mesin genset, bekerjasama dengan operator TUKG untuk memberikan pelatihan singkat dan memandu guru tersebut tentang tata cara mengoperasikan komputer dan internet pada aplikasi UKG, serta Mengikutsertakan guru pada Uji Kompetensi Awal (UKA) secara Online.

\section{SARAN}

Dari beberapa poin kesimpulan tersebut di atas, maka peneliti dapat memberikan saran sebagai berikut :

1. Kepada Kementerian Pendidikan dan Kebudayaan melalui Dinas Pendidikan Kabupaten agar lebih meningkatkan sosialisasi dan pelatihan mengenai pelaksanaan Uji Kompetensi Guru sehingga para guru memiliki persiapan yang matang dalam mengikuti kegiatan UKG tersebut dengan rentang waktu cukup yang sesuai bagi guru yang mengikuti UKG tersebut.

2. Kepada Dinas Pendidikan Kabupaten agar memberikan kesempatan bagi para guru untuk berlatih mengerjakan soal yang polanya tidak berbeda jauh dengan Uji Kompetensi Guru Online dengan mengikuti Kompetensi Awal (UKA).

3. Kepada para guru untuk tetap optimis dalam mengikuti uji kompetensi guru sebagai salah satu langkah untuk memperbaiki kualitas dan menjadi tolak ukur bagi Penilaian Kinerja Guru (PKG) yang berdampak pada hak jumlah jam pelajaran yang diampu perminggu. 
P-ISSN 2580 - 7781

E-ISSN 2615 - 3238

\section{DAFTAR PUSTAKA}

Ali Mahmudi. (2009). Mengembangkan Kompetensi Guru Melalui Lesson Study. Jurnal Forum Kependidikan, 28(2), 84-89.

Janawi (2011), Kompetensi Guru : Citra Guru Profesional, Bandung, Alfabeta.

Kuswana, D ( 2011). Metode Penelitian Sosial. Bandung ,Pustaka Setia.

Mimbar, , \& Dasar. (2014). IDENTIFIKASI KOMPETENSI GURU SEBAGAI CERMINAN PROFESIONALISME TENAGA PENDIDIK DI KABUPATEN SUMEDANG 1) Reni Fahdini 1 , 2) Ence Mulyadi, 3) Deni Suhandani, 4) Julia, 1(April), 33-42. https://doi.org/10.17509/mimbar-sd.v1i1.1362

Muhson, A. (2004). Meningkatkan Profesionalisme Guru: Sebuah Harapan. Jurnal Ekonomi \& Pendidikan, 2(1), 90-98.

Nasir, M. (2013). Profesionalisme Guru Agama Islam: Sebuah Upaya Peningkatan Mutu melalui LPTK. Dinamika Ilmu, 13(2), 189-203. https://doi.org/10.21093/di.v13i2.25

Nurhayati, B. (2006). Faktor-Faktor yang mempengaruhi profesionalisme dan kinerja guru Biologi di SMAN Kota Makassar Sulawesi Selatan. Mimbar Pendidikan, 4(25), 64-70.

Pasolong, Harbani (2011),Teori Administrasi Publik, Bandung : Alfabeta

Sanaky, H. A. (2005). Sertifikasi dan profesionalisme guru di era reformasi pendidikan. Jurnal Pendidikan Islam, 1, 1-13.

Sauri, S. (2008). Membangun profesionalisme guru berbasis nilai bahasa santun bagi pembinaan keperibadian bangsa yang bijak. Pidato Guru Besar, 1-34.

Sugiyono (2014), Memahami Penelitian Kualitatif, Bandung ,Alfabeta.

Suhandani, D., \& Julia, J. (2014). Identifikasi Kompetensi Guru Sebagai Cerminan Profesionalisme Tenaga Pendidik Di Kabupaten Sumedang (Kajian Pada Kompetensi Pedagogik). Mimbar Sekolah Dasar, 1(2), 128-141.

Supriadi, O. (2009). Pengembangan Profesionalisme Guru Sekolah Dasar. JurnalTabularasa PPS Unimed, 6(1), 27-38.

Winarno, B (2012), Kebijakan Publik : Teori, Proses dan Studi Kasus, Yogyakarta,CAPS.

Undang-undang Republik Indonesia Nomor 20 Tahun 2003 tentang Sistem Pendidikan Nasiona

Undang-Undang Nomor 14 Tahun 2005 tentang Guru dan Dosen

Peraturan Menteri Pendidikan Nasional Republik Indonesia Nomor 16 Tahun 2007 tentang Standar Kualifikasi Akademik dan Kompetensi Guru

Surat Edaran Resmi Dirjen GTK Nomor 2825/B/PR/2017 tertanggal 14 Agustus 2017 tentang Pelaksanaan UKG tahun 2017. 